\title{
An Investigation of the Factors That Influence the Perception of Small and Medium Sized Business Employees and Owners on Accounting Information Systems in Jordan
}

Osama Shaddad (Corresponding author)

Assistant Professor at Jadara University, Faculty of Economic and Business

Jordan

Email: shaddad8@hotmail.com

\begin{abstract}
Nawwaf Alfawa'rah
Assistant Professor at Jadara University, Faculty of Economic and Business

Accounting Department, Jordan
\end{abstract}

\begin{abstract}
Bader Alqaied
Assistant Professor at Ajloun National University, Faculty of Business Administration Jordan
\end{abstract}

George Shawaqfeh

Assistant Professor at Ajloun National University, Faculty of Business Administration Jordan

Accepted: May 29, 2015

DOI: 10.5296/ijafr.v5i1.7658 URL: http://dx.doi.org/10.5296/ ijafr.v5i1.7658

\begin{abstract}
The study investigates the perceptions that small and medium sized businesses in Amman (Jordan) have towards the adoption of accounting information systems. The literature review reveals that performance and productivity are not directly influenced by accounting information systems. The research paper uses a cross sectional survey design with an interview to collect data. The study is limited to Amman (Jordan) due to monetary and time restrictions. The research paper reveals that the size of the organization and the education
\end{abstract}


level influence the perception of survival without accounting information systems, while the size and position of the respondents determine influences the perception of cost in an organization.

Keywords: Small and medium sized business, Amman (Jordan), Accounting Information System, Performance, Productivity

\section{Introduction}

\subsection{Background of the study}

Information technology has influenced all facets of life. One of the main areas that have considerably been influenced is accounting. The evolution of accounting information systems has provided companies with better control and management of their finances and their entire economic overview. Accounting systems have been used by most large companies and corporations to adhere to new accounting standards such as IFRS and GAAP (Romney and Steinbart, 2006). The accounting systems also aid in the auditing of financial records of any company. Forensic accounting and proper use of accounting information systems has improved the overall management of finances for most large corporations. However, this is not the same trend in small and medium sized enterprises.

\subsection{Statement of the problem}

There are many issues that have hindered the adoption of accounting information systems in medium and small companies. The first reason is the added cost of purchasing the accounting information systems. This type of software is quite expensive, and most small companies are struggling to remain profitable. This lack of finance limits the adoption of accounting information systems in most medium and small sized companies. In addition to this, there is a lack of education. Most medium and small companies are start-ups. These start-ups are limited in the number of employees (Hall, 2001). Therefore, they only hire employees with limited skills because they cannot compete with the hiring standards of large scale employees. The small and medium companies cannot hire people who have the skills to use these accounting information systems. These are some of the issues that may limit the adoption of accounting information systems in medium and small companies. This also leads many entrepreneurs to question the importance of accounting information systems for such companies. The research paper provides a brief investigation of the benefit that small and medium firms can have for adopting accounting information systems and the limitations of adopting this software.

\subsection{Aims and objectives of the study}

As highlighted, the aim of the study is to investigate the perceptions of owners and employee benefits that small and medium firms can have for adopting accounting information systems and the limitations of adopting such software. This aim can be subdivided into three specific objectives that the research paper seeks to fulfil. The research objectives are:

To determine whether there is a relationship between the size of the company, experience of using the software, whether the person is the owner and education level of people 
working in a small and medium sized company

$>$ To determine if there is a relationship between the perception of the survival of a company without adoption of accounting information systems and the size of the company, experience of using the software, whether the person is the owner and education level of people working in a small and medium company

$>$ To determine whether there is a relationship between the perception of the cost of adopting accounting information systems and the size of the company, experience of using the software, whether the person is the owner and education level of people working in a small and medium company

The research objectives look at three main subsections of benefits, limitations and improvement of accounting information systems adoption. The research objectives are then converted to the following research questions:

What factors are assumed to have a relationship with accounting information system adoption and is there a relationship between these factors?

$>$ Is the perception of the survival of a company without adoption of accounting information systems is influenced by the size of the company, experience of using the software, whether the person is the owner and education level of the respondent?

$>$ Is the perception of the cost of adopting accounting information systems is influenced by the size of the company, experience of using the software, whether the person is the owner and education level of the respondent?

\subsection{Importance of the study}

There are several reasons why this study is important. The first is to determine the perception that the owners or workers in small and medium firms have towards accounting information systems. Many people in the academic field or large corporations believed that the benefits that are accrued from accounting information systems outweigh the cost of implementing the technology (Sjögrén, Syrjä and Puumalainen, 2014). However, the situation may be different in small and medium sized businesses. There are few studies that provide an assessment of the perceptions of the small and medium sized business employees and the owners. The perceptions provided by the study will provide important insight on the adoption of accounting systems (Urquía Grande, Pérez Estébanez and Muñoz Colomina, 2011). This will allow accounting systems companies and the government to learn the best way to push SMEs to adopt these systems in their business models.

The study also investigated the limitations for adoption of this software. Large business enterprises are required to adopt certain accounting systems in order to receive government licenses. However, small and medium sized businesses cannot be legally mandated to adopt these accounting systems (Gunasekaran and Sandhu, 2010). The reason behind this is that small and medium firms are mainly start-ups with limited finances. Additional mandatory costs will limit the start and the growth of such companies. Therefore, it is important to ensure that such companies adopt this technology willingly (De Marco, 2012). This can only be done by reducing the hindrances that these companies have on the adoption of new technology. 


\section{Macrothink}

International Journal of Accounting and Financial Reporting

ISSN 2162-3082

2015, Vol. 5, No. 1

\subsection{Scope of the study}

The study provides an investigation of the perceptions that employees and owners of small and medium companies on the accounting information system. The research covers Amman(Jordan) due to limitations of time and money. This provides an updates localized report on perceptions within Amman(Jordan).

\subsection{Limitations of the study}

The main limitation of the study is the limited amount of time and money which does not allow a larger sample to be collected or a sample that covers more than one geographical region. The study also generalizes all accounting software, and this limits the determination of the preferences based on the make of the accounting software.

\subsection{Literature review}

There have been several studies that have investigated the state and the importance of the adoption of accounting information systems. Researchers, such as McGrath (2006), have found that adoption of accounting information systems provides a platform where there is better management of the company's finances (McGrath, 2006). There is no direct benefit that accounting information systems provide to an organization, except the better management of resources and finances.

\subsection{Accounting information system and performance}

While the information on how exactly accounting information systems influence the performance of an organization, there are several researchers who have attempted to investigate this phenomenon. A study by Ismail and King (2005) highlighted that there is a positive association between performance measures and strategies of small and medium companies with alignment with accounting information systems. Other researchers like Naranjo (2004) found that accounting information systems indirectly influence the performance of an organization by streamlining the other factors of production especially capital. Additionally, Damanpour and Gopalakrishnan (2001) suggest that performance and accounting information systems have a cause and effect relationship. The main issue is the technological investment involved with adoption of accounting information systems. Other researchers, such as Wah (2000) suggest that adoption of accounting information systems in a small and medium sized organization is followed by an initial dip in performance before the employees and the organizational culture adjust and thereafter an increase in performance. In relation to perception, many of the owners find the investment cost to be steep. Adoption of accounting information systems requires purchase of computers and the purchase of the accounting software. This is an additional cost that is outside the delivery of services that small and medium business enterprises thrive on (Greenhalgh, 2000). Additional studies suggest that adoption of accounting information systems normally leads to frustration due to failure to achieve the expected performance improvements. This means that different researchers have attained different results.

\subsection{Accounting information systems and productivity}

While performance is concerned with the improvement of factors like production, productivity refers to increase in efficiency by the factors of production. When looking at the literature on productivity due to information technology adoption, it is important to note that 


\section{MInstitute Macrothink $_{\text {Int }}^{\text {Intis }}$}

International Journal of Accounting and Financial Reporting ISSN 2162-3082 2015, Vol. 5, No. 1

most researchers suggest that the only way to determine this is by looking at the country development (Felski and Jaskólski, 2012). A study by Hitt and Brynjolfsson (1998) highlighted that the productivity paradox limits that productivity measures in an organization. The productivity paradox suggests that the benefits in productivity are translated into benefits to the customers and not the business (Brynjolfsson and Hitt, 1998). This makes it hard to measure or to derive any specific benefits. However, non-adopting companies suffer from decreases in productivity due to competition from companies that have embraced accounting information systems. In terms of perception, it seems that owners will find it difficult to understand the need for adoption because there are no tangible benefits that can be seen.

\subsection{Research Methodology}

\subsection{Research Approach}

Any research requires determining whether secondary or primary data will be used in answering the research questions. Secondary data is the easiest data to collect because it only requires the review of previous studies. However, the secondary data collected may not be good for fulfilling the research objectives. Primary data is hard to collect, but this information allows the objectives to be fulfilled using specific data analysis methods. Any primary study can be of two main types. A cross-sectional study is the first type of primary survey that can be done. This involves providing a snapshot of the characteristics of the population as well as the relationship between the sample variables (Cohen, Manion and Morrison, 2000). The other type of primary survey is a longitudinal study. This type of survey is done at two periods of time. The first period involves determination of the initial population characteristics and then a treatment is introduced. After the treatment, another data collection is done in order to determine the treatment effects in the study. The research uses a cross-section survey design in order to obtain a snapshot of the perceptions that small and medium firm owners and employees have towards the use of accounting information systems.

\subsection{Sampling criteria}

The development of a sampling criteria is another important part when undertaking research. The creation of sampling criteria needs to adhere to the principles of experimentation. The sampling criteria is the creation of a sampling frame that is made up of 50 businesses around Amman. This sampling frame is selected at random in order to ensure that the randomization principle of experimentation is maintained. After that, the research selects twenty-five of the businesses from the sampling frame using the random number function in a calculator. From each business, four people are interviewed, and this provides information on the perceptions that the owners and the employees have towards the use of accounting information systems (Creswell and Plano Clark, 2007). The investigators ask questions based on the questionnaire and then saves the information in the laptop to ease the entry of data. This allows clarification of information and missing data is avoided in the study. The principle of replication is adhered to by the selection of more than one person in each business as well as the selection of 100 participants in the research. The principle of local control is adhered to by selecting businesses in Amman. This ensures that the variables that influence business like the taxes and regulations are the same. 


\subsection{Hypothesis development}

Hypothesis development is important when answering questions using empirical means. The study seeks to answer the following research questions:

$>$ What factors are assumed to have a relationship with accounting information system adoption and is there a relationship between these factors?

$>$ Is the perception of the survival of a company without adoption of accounting information systems is influenced by the size of the company, experience of using the software, whether the person is the owner and education level of the respondent?

$>$ Is the perception of the cost of adopting accounting information systems is influenced by the size of the company, experience of using the software, whether the person is the owner and education level of the respondent?

The hypothesis developed include an investigation of whether there is any relationship between the factors that influence the perception of accounting information system . The factors identified in the study are the size of the company, whether the person is an owner or employee, the level of education and experience with education systems (Inglehart, 2000). The hypothesis developed is:

H0: The size of an organization, whether the person is an owner or employee, education level and the experience with accounting information systems do not have a relationship.

H1: The size of an organization, whether the person is an owner or employee, education level and the experience with accounting information systems have a relationship.

The next research question investigated whether there the perception that a company can survive without adoption of accounting information systems is influenced by the size of the company, experience of using the software, whether the person is the owner and education level of the respondent. This leads to the following hypothesis:

H0: Perception that a company can survive without adoption of accounting information systems is not influenced by the size of the company, experience of using the software, whether the person is the owner and education level of the respondent

H1: Perception that a company can survive without adoption of accounting information systems is influenced by the size of the company, experience of using the software, whether the person is the owner and education level of the respondent

This is a regression hypothesis that is based on the following model:

$$
\bar{Y}=\alpha+\beta_{1} X_{1}+\beta_{2} X_{2}+\beta_{3} X_{3}+\beta_{4} X_{4}
$$

The next research question queried whether the perception of cost of investment was influenced by the size of the company, experience of using the software, whether the person is the owner and education level of the respondent. Thisis given in the following hypothesis:

H0: Perception of cost of adopting accounting information systems is not influenced by the size of the company, experience of using the software, whether the person is the owner and education level of the respondent

H1: Perception of cost of adopting accounting information systems is influenced by the size 


\section{Mll Macrothink}

International Journal of Accounting and Financial Reporting ISSN 2162-3082 2015, Vol. 5, No. 1

of the company, experience of using the software, whether the person is the owner and education level of the respondent

This is also answered using a regression equation with the following model:

$$
\bar{Y}=\alpha+\beta_{1} X_{1}+\beta_{2} X_{2}+\beta_{3} X_{3}+\beta_{4} X_{4}
$$

\subsection{Data Collection}

Data collection involves the determination of the types of data that will be collected. Data can be either qualitative or quantitative. Qualitative data is data that is nonnumerical in nature. This type of data is hard to analyse using numerical analysis techniques. However, qualitative analysis allows for the adoption of small samples. On the other hand, quantitative data analysis is the collection of empirical or numerical data. This type of data is easier to analyse, but it requires the collection of data from a large sample in order to be acceptable. Additionally, it is more suited for laboratory experiments rather than human related studies (Govaert, 2009). Both types of data have advantages and detriments, but the researchers found a way to combine the collection and the analysis of both types of data. Thisis known as a mixed method data collection. The data can be either predominantly qualitative or predominantly quantitative. The research uses a predominantly qualitative mixed method data collection method where the data are collected in terms of a dichotomous key or a Likert scale. This reduces the sample size required and allows the use of empirical methods of data collection and analysis.

\subsection{Data Analysis Methods}

The research methods also determined the type of data analysis that is conducted in the study. Since the data collected is done using mixed methods, statistical software can be used. SPSS is the statistical software chosen in both the collection and the analysis of the data. The main reason for this is the use of the labels function in the SPSS in order to collect information that is already coded. This reduces the time used in data collection as well as data analysis. The data analysis methods used are a combination of inferential and descriptive data analysis methods. Descriptive analysis involves the use of frequency tables made using the mode as the central tendency measure because of the nature of the data (Sarantakos, 2007). Inferential analysis involves conducting correlation and regression analysis in order to ascertain the nature of the variables. The results are discussed to answer the research questions in the table.

\subsection{Ethical Considerations in the Study}

Any study also requires ethical considerations to be made especially when human respondents are involved. The study asks some sensitive information that can legally be used by the respondents. Therefore, the identity of the businesses and the respondents has to be protected in the study. This is done by keeping all names confidential. This protects the identity of the businesses and the respondents to allow the study to keep the information safe.

\subsection{Data Analysis}

\subsection{Descriptive analysis}

Descriptive analysis investigated the characteristics of the data collected. Particular attention is paid to the demographic variables that will be used as independent variables in the study. 
This is done using the frequency function in SPSS where the mode is selected as the central tendency measure.

The first demographic variable collected investigated the size of the business that the sample participant worked. The results indicate that the study indicate that 51 are from small businesses while 49 are from medium sized companies. A graphical representation is shown.

size

\begin{tabular}{|ll|l|l|l|l|}
\hline & Frequency & Percent & Valid Percent & $\begin{array}{l}\text { Cumulative } \\
\text { Percent }\end{array}$ \\
\hline Valid & Small & 51 & 51.0 & 51.0 & 51.0 \\
& Medium & 49 & 49.0 & 49.0 & 100.0 \\
& Total & 100 & 100.0 & 100.0 & \\
\hline
\end{tabular}

Table 1: Size of the business

The study then investigated the position that the sample participants held in the company. Forty-five of them were business owners while 55 were simply employees in the organization. Graphically this is shown as follows.

position

\begin{tabular}{|c|c|c|c|c|c|}
\hline & & Frequency & Percent & Valid Percent & $\begin{array}{l}\text { Cumulative } \\
\text { Percent }\end{array}$ \\
\hline \multirow[t]{3}{*}{ Valid } & owner & 45 & 45.0 & 45.0 & 45.0 \\
\hline & employee & 55 & 55.0 & 55.0 & 100.0 \\
\hline & Total & 100 & 100.0 & 100.0 & \\
\hline
\end{tabular}

Table 2: Position in the business

The study then investigated the education level of the sample participants. Twenty-eight of them had studied to high school level while 31 had studied diplomas in college. An additional twenty-four had studied in university with seventeen having post graduate qualifications. This is graphically shown below. 


\section{Macrothink \\ International Journal of Accounting and Financial Reporting

Education level

\begin{tabular}{|ll|l|l|l|l|}
\hline & Frequency & Percent & Valid Percent & $\begin{array}{l}\text { Cumulative } \\
\text { Percent }\end{array}$ \\
\hline Valid & high school & 28 & 28.0 & 28.0 & 28.0 \\
diploma & 31 & 31.0 & 31.0 & 59.0 \\
university & 24 & 24.0 & 24.0 & 83.0 \\
post graduate & 17 & 17.0 & 17.0 & 100.0 \\
Total & 100 & 100.0 & 100.0 & \\
\hline
\end{tabular}

Table 3: Education level

The final demographic factor involved determining the experience that the respondents had experience of using accounting information systems. The results indicate that 79 had experience using the software while 21 did not have this experience.

\section{Experience with AIS}

\begin{tabular}{|ll|l|l|l|l|}
\hline & Frequency & Percent & Valid Percent & $\begin{array}{l}\text { Cumulative } \\
\text { Percent }\end{array}$ \\
\hline Valid $\quad$ yes & 79 & 79.0 & 79.0 & 79.0 \\
& no & 21 & 21.0 & 21.0 & 100.0 \\
& Total & 100 & 100.0 & 100.0 & \\
\hline
\end{tabular}

Table 4: Education with AIS

Aside from demographic information, there is additional information investigated based on a Likert scale. First the study investigated the perception of respondents on their companies surviving without accounting information systems. The results indicate that twenty-two of the strongly agree while fourteen agree that companies can survive without accounting information systems. Twenty-five were neutral; twenty-one disagree while an additional eighteen strongly disagreeing that companies can survive without adopting accounting information systems. This is graphically shown below. 


\section{Al Macrothink \\ International Journal of Accounting and Financial Reporting ISSN 2162-3082 2015, Vol. 5, No. 1}

Survive without AIS

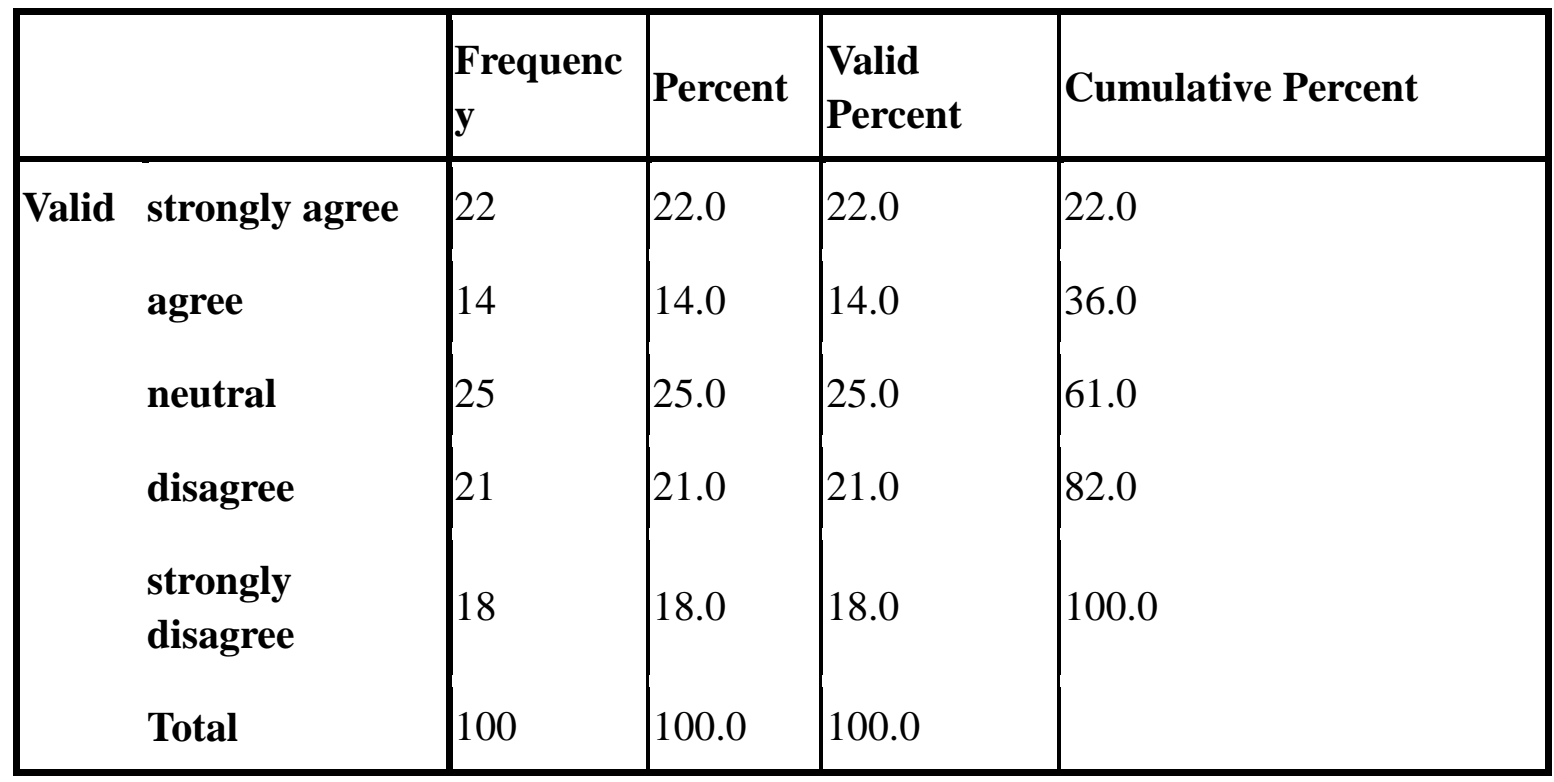

Table 5: Survival without AIS adoption

The study then queried whether the companies gained a competitive advantage from the adoption of accounting information systems. The results indicate that seventeen of them strongly agree while twenty agree that companies gain a competitive advantage by adopting accounting information systems. Twenty-two were neutral; sixteen disagree while an additional twenty-five strongly disagreeing that companies gain a completive advantage by adopting accounting information systems. This is graphically shown below.

\section{Competitive advantage}

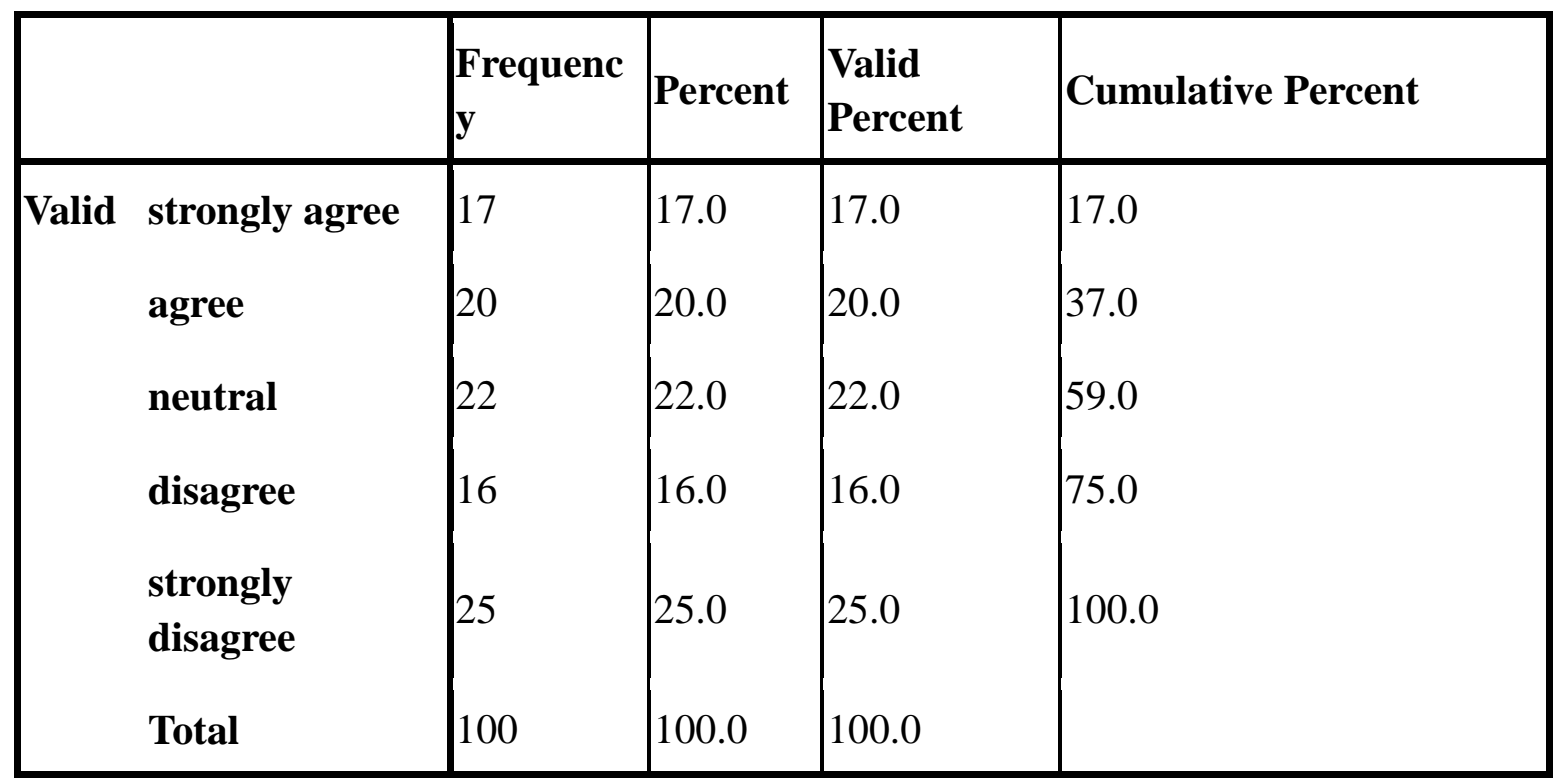

Table 6: Competitive advantage

The study then investigated whether cost was a hindrance to the adoption of accounting information systems. The results indicate that thirty of them strongly agree while thirty-six agree that the cost was a hindrance to adoption of accounting information systems. 
Thirty-four were neutral. This is shown graphically below.

\section{Cost hindrance}

\begin{tabular}{|l|l|l|l|l|}
\hline & Frequenc & Percent & $\begin{array}{l}\text { Valid } \\
\text { Percent }\end{array}$ & Cumulative Percent \\
\hline $\begin{array}{l}\text { Valid } \begin{array}{l}\text { strongly } \\
\text { agree }\end{array} \\
\text { agree }\end{array}$ & 36 & 30.0 & 30.0 & 30.0 \\
neutral & 34 & 34.0 & 34.0 & 66.0 \\
Total & 100 & 100.0 & 100.0 & 100.0 \\
\hline
\end{tabular}

Table 7: Cost hindrance

\subsection{Inferential Analysis}

Inferential analysis involves the analysis of the relationships between variables to answer the hypothesis in the study. The first is a correlation in order to determine how to input the regression models afterward. The correlation analysis involved investigated the relationship between sizes of an organization, whether the person is an owner or employee, education level and the experience with accounting information systems.

\section{Correlations}

\begin{tabular}{|c|c|c|c|c|c|}
\hline & & size & position & $\begin{array}{l}\text { Education } \\
\text { level }\end{array}$ & $\begin{array}{l}\text { Experience } \\
\text { with AIS }\end{array}$ \\
\hline \multirow[t]{3}{*}{ size } & $\begin{array}{l}\text { Pearson } \\
\text { Correlation }\end{array}$ & 1 & -.119 & -.051 & -.063 \\
\hline & Sig. (2-tailed) & & .240 & .612 & .531 \\
\hline & $\mathbf{N}$ & 100 & 100 & 100 & 100 \\
\hline \multirow[t]{3}{*}{ position } & $\begin{array}{l}\text { Pearson } \\
\text { Correlation }\end{array}$ & -.119 & 1 & -.067 & .022 \\
\hline & Sig. (2-tailed) & .240 & & .509 & .826 \\
\hline & $\mathbf{N}$ & 100 & 100 & 100 & 100 \\
\hline \multirow[t]{3}{*}{ Education level } & $\begin{array}{l}\text { Pearson } \\
\text { Correlation }\end{array}$ & -.051 & -.067 & 1 & $.506^{* *}$ \\
\hline & Sig. (2-tailed) & .612 & .509 & & .000 \\
\hline & $\mathbf{N}$ & 100 & 100 & 100 & 100 \\
\hline
\end{tabular}




\begin{tabular}{|lc|l|l|l|l|}
\hline $\begin{array}{l}\text { Experience } \\
\text { AIS }\end{array}$ & with $\begin{array}{l}\text { Pearson } \\
\text { Correlation }\end{array}$ & -.063 & .022 & $.506^{* *}$ & 1 \\
& Sig. (2-tailed) & .531 & .826 & .000 & 100 \\
& $\mathbf{N}$ & 100 & 100 & 100 & 100 \\
\hline
\end{tabular}

**. Correlation is significant at the 0.01 level (2-tailed).

Table 8: Correlation table

Correlations that are significant are measured using a 0.08 Pearson's correlation value. The results of the correlation analysis indicate that there is a relationship between the position in the organization and the size of the organization with a -0.119 Pearson's correlation value that indicates a weak inverse correlation. There is also a significant correlation between the education level and experience with accounting information systems with a Pearson's correlation value of 0.506 which indicates a strong positive correlation.

After that, regression analysis is performed to determine the relationship between the independent variables and survival perception in the study. The first is a model summary of the study.

\section{Model Summary}

\begin{tabular}{|c|c|c|c|c|}
\hline Model & $\mathbf{R}$ & R Square & $\begin{array}{l}\text { Adjusted } \\
\text { Square }\end{array}$ & $\mathbf{R}$ Std. Error of the Estimate \\
\hline 1 & $.771^{\mathrm{a}}$ & .529 & $\mid-.412$ & 1.412 \\
\hline
\end{tabular}

a. Predictors: (Constant), experience with AIS, position, size, education level

Table 9: Model Summary 1

The model summary indicates that the R-square is 0.529 , and this represents a 52.9 percent variation caused by the independent variables.

ANOVA $^{b}$

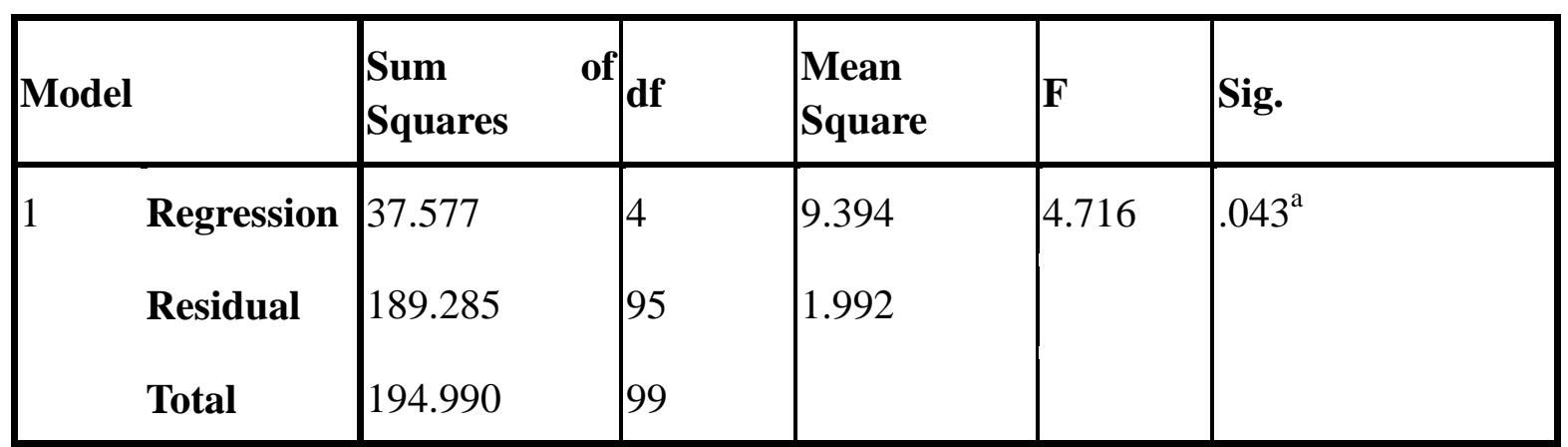

a. Predictors: (Constant), experience with AIS, position, size, education level 
b. Dependent Variable: survive without AIS

\section{Table 10: ANOVA}

The results indicate that there is a $4.716 \mathrm{~F}$ value with a $0.043 \mathrm{p}$-value. This indicates that the model selected in the study is a good fit.

\section{Coefficients}

\begin{tabular}{|c|c|c|c|c|c|c|}
\hline \multirow{2}{*}{\multicolumn{2}{|c|}{ Model }} & \multicolumn{2}{|c|}{$\begin{array}{l}\text { Unstandardized } \\
\text { Coefficients }\end{array}$} & \multirow{2}{*}{\begin{tabular}{|l} 
Standardized \\
Coefficients
\end{tabular}} & \multirow{2}{*}{$\mathbf{T}$} & \multirow{2}{*}{ Sig. } \\
\hline & & B & Std. Error & & & \\
\hline \multirow[t]{5}{*}{1} & (Constant) & 3.533 & .813 & & 4.344 & .000 \\
\hline & size & -.147 & .285 & -.653 & -2.516 & .028 \\
\hline & position & .114 & .287 & .041 & .397 & .692 \\
\hline & Education level & .119 & .156 & .790 & 4.761 & .009 \\
\hline & $\begin{array}{l}\text { Experience with } \\
\text { AIS }\end{array}$ & -.639 & .403 & -.186 & -1.587 & .116 \\
\hline
\end{tabular}

a. Dependent Variable: survive without AIS

\section{Table 11: Coefficients}

The coefficients table indicates that there is a relationship between the size of the company and the education level of the employee in the organization. The study then investigates whether the perception that the cost is a hindrance to the adoption of accounting information systems is influenced by the demographic factors.

\section{Model Summary}

\begin{tabular}{|c|c|c|c|c|}
\hline Model & $\mathbf{R}$ & R Square & $\begin{array}{l}\text { Adjusted } \\
\text { Square }\end{array}$ & $\mathbf{R}$ Std. Error of the Estimate \\
\hline 1 & $.764^{\mathrm{a}}$ & .533 & .496 & .763 \\
\hline
\end{tabular}

a. Predictors: (Constant), experience with AIS, position, size, education level 
Table 12: Model Summary 2

The model summary indicates that the R-square is 0.533 , and this represents a 53.3 percent variation caused by the independent variables.

ANOVA $^{b}$

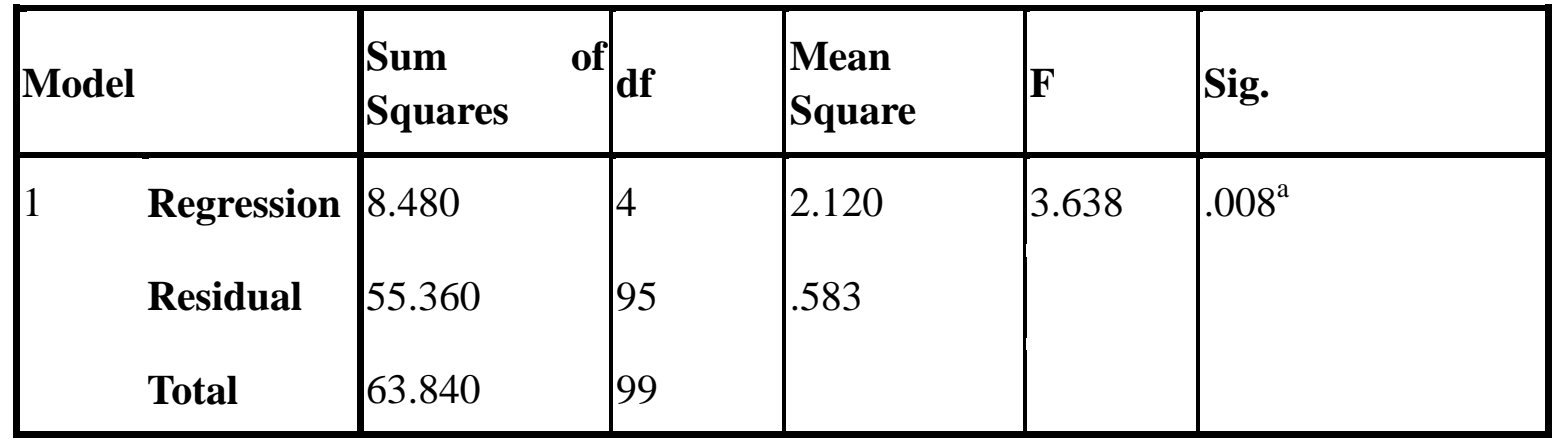

a. Predictors: (Constant), experience with AIS, position, size, education level

b. Dependent Variable: cost hindrance

\section{Table 13: ANOVA 2}

The results indicate that there is a $3.638 \mathrm{~F}$ value with a $0.008 \mathrm{p}$-value. This indicates that the model selected in the study is a good fit.

\section{Coefficients}

\begin{tabular}{|c|c|c|c|c|c|c|}
\hline \multirow{2}{*}{\multicolumn{2}{|c|}{ Model }} & \multicolumn{2}{|c|}{$\begin{array}{l}\text { Unstandardized } \\
\text { Coefficients }\end{array}$} & \multirow{2}{*}{ 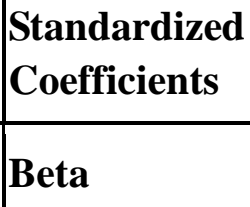 } & \multirow[t]{2}{*}{$\mathbf{T}$} & \multirow[t]{2}{*}{ Sig. } \\
\hline & & B & Std. Error & & & \\
\hline \multirow[t]{5}{*}{1} & (Constant) & 3.610 & .440 & & 8.207 & .000 \\
\hline & size & -.347 & .154 & -.217 & -2.248 & .027 \\
\hline & position & -.446 & .155 & -.278 & -2.873 & .005 \\
\hline & Education level & .012 & .084 & .015 & .137 & .891 \\
\hline & $\begin{array}{l}\text { Experience with } \\
\text { AIS }\end{array}$ & -.322 & .218 & -.164 & -1.477 & .143 \\
\hline
\end{tabular}

a. Dependent Variable: cost hindrance

\section{Table 14: Coefficients 2}

The results show that the perception that the cost is a hindrance is caused by the size of the organization as well as the position of the sample respondents in the organization.

\subsection{Data Analysis Discussions}

The data analysis answers fulfil all the hypothesis developed in the research methodology stage. The first hypothesis is: 


\section{Mll Macrothink}

International Journal of Accounting and Financial Reporting

H0: The size of an organization, whether the person is an owner or employee, education level and the experience with accounting information systems do not have a relationship.

H1: The size of an organization, whether the person is an owner or employee, education level and the experience with accounting information systems have a relationship.

The results of the correlation analysis indicate that there is a significant correlation between four variables and, therefore, the null hypothesis is rejected. The alternative is accepted. The correlation is between the size of the organization and the position of the participant as well as the education level and the experience level.

The second hypothesis is:

H0: Perception that a company can survive without adoption of accounting information systems is not influenced by the size of the company, experience of using the software, whether the person is the owner and education level of the respondent

H1: Perception that a company can survive without adoption of accounting information systems is influenced by the size of the company, experience of using the software, whether the person is the owner and education level of the respondent

The regression analysis was positive with a good model fit and a good model summary. The p-value is lower than a 0.05 alpha value. This indicates that the independent variables have a significant effect on the perception of survival of small businesses without the use of accounting information systems. In particular, size and the education level had the significant effect on the perception of survival.

The third hypothesis is:

H0: Perception of cost of adopting accounting information systems is not influenced by the size of the company, experience of using the software, whether the person is the owner and education level of the respondent

H1: Perception of cost of adopting accounting information systems is influenced by the size of the company, experience of using the software, whether the person is the owner and education level of the respondent

This regression model is also a good fit with a p-value that is less than a 0.05 alpha. This means that the null hypothesis is rejected while alternative hypothesis is accepted. In particular, the size of the respondents and the position in the organization greatly influence the perception.

\subsection{Conclusion and Recommendation}

\subsection{Conclusion}

The research paper has identified that accounting information systems highlight an advantage in the performance and the productivity of the organization. However, the effect is not direct on performance and, therefore, there are no visible results. The productivity is also subject to the productivity paradox where the benefits fall to the customers rather than the business. The literature review suggests that the employees and the owners will not see any direct benefit from the adoption of accounting information system adoption. This means that the perceptions will be inclined towards not adopting the accounting information system. Thisis seen in the results were in most cases the respondents either disagreed more or were neutral. 


\section{Macrothink}

International Journal of Accounting and Financial Reporting ISSN 2162-3082 2015, Vol. 5, No. 1

The notion that companies could survive without adoption by accounting information systems is influenced by the size of the organization and the education level. The participants who were in smaller businesses believed that the company could survive without the adoption of accounting information systems. The education level was correlated with the experience in using accounting information systems and, therefore, the more a person is educated, the more likely they are to adopt accounting information systems.

The research also revealed that the cost of implementation of accounting information system is influenced by the size and the position of the organization. Small organization had a higher perception of cost being a hindrance to the adoption of accounting information systems. In addition to this, all the respondents who were owners of businesses highlighted that cost is a major hindrance to the adoption of accounting information systems.

\subsection{Recommendations}

The study has highlighted expertise and cost as the main hindrances for adoption of accounting information systems in small and medium companies. The government can provide training for medium and small companies. This will boost knowledge and expertise to increase accounting information systems adoption. Accounting information systems can also offer completely web-based solutions where the small businesses do not need to purchase any software and instead only pay a small subscription. This will increase the adoption of accounting information systems.

\section{References}

Brynjolfsson, E. and Hitt, L. (1998). Beyond the productivity paradox. Commun. ACM, 41(8), pp.49-55.

Cohen, L., Manion, L. and Morrison, K. (2000). Research methods in education. London: RoutledgeFalmer.

Creswell, J. and Plano Clark, V. (2007). Designing and conducting mixed methods research. Thousand Oaks, Calif.: SAGE Publications.

Damanpour, F. and Gopalakrishnan, S. (2001). The Dynamics of the Adoption of Product and Process Innovations in Organizations. J Management Studies, 38(1), pp.45-65.

De Marco, M. (2012). Information systems. Heidelberg: Physica-Verlag.

Felski, A. and Jaskalski, K. (2012). Information Unfitness of AIS. Annual of Navigation, 19(1).

Govaert, G. (2009). Data analysis. London: ISTE.

Greenhalgh, R. (2000). Information and the transnational SME controller. Management Accounting Research, 11(4), pp.413-426.

Gunasekaran, A. and Sandhu, M. (2010). Handbook on business information systems. Singapore: World Scientific.

Hall, J. (2001). Accounting information systems. Cincinnati, Ohio: South-Western College Pub.

Inglehart, W. (2000). Hypothesis. New York, N.Y.: Vantage Press. 


\section{Macrothink}

International Journal of Accounting and Financial Reporting

ISSN 2162-3082 2015, Vol. 5, No. 1

Ismail, N. and King, M. (2005). Firm performance and AIS alignment in Malaysian SMEs. International Journal of Accounting Information Systems, 6(4), pp.241-259.

McGrath, K. (2006). Affection not affliction: The role of emotions in information systems and organizational change. Information and Organization, 16(4), pp.277-303.

Naranjo, (2004). The Role of Sophisticated Accounting System in Strategy Management. IJDAR.

Romney, M. and Steinbart, P. (2006). Accounting information systems. Upper Saddle River, N.J.: Pearson Prentice Hall.

Sarantakos, S. (2007). Data analysis. Los Angeles: SAGE.

S, H., Syria, P. and Puumalainen, K. (2014). Use of management accounting information in SMEs - role of service provider relationships. IJBIS, 17(3), p.340.

Teittinen, H., Pellinen, J. and JarvenpÃ̊Ãa, M. (2013). ERP in action" Challenges and benefits for management control in SME context. International Journal of Accounting Information Systems, 14(4), pp.278-296.

Urqua Grande, E., Parez Estabanez, R. and Muaoz Colomina, C. (2011). The impact of Accounting Information Systems (AIS) on performance measures: empirical evidence in Spanish SMEs. IJDAR, 11. 